\title{
MASTER
}

\section{THE USE OF THE PULP AND PAPER INDUSTRY PROCESS MODEL FOR R\&D DECISION MAKING}

David A. Pilati and Richard Rosen

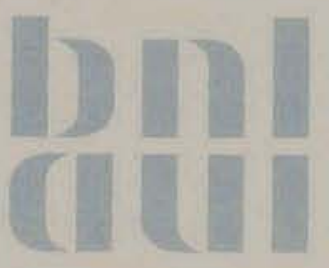

March 1978

Prepared for the

DIVISION OF INDUSTRIAL CONSERVATION

UNITED STATES DEPARTMENT OF ENERGY

BY THE

ECONOMIC ANALYSIS DIVISION

DEPARTMENT OF ENERGY AND ENVIRONMFNT

BROOKHAVEN NATIONAL LABORATORY

ASSOCIATED UNIVERSITIES, INC.

UNDER CONTRACT NO. EY-76-C-02-0016 WITH THE

UNITED STATES DEPARTMENT OF ENERGY 


\section{DISCLAIMER}

This report was prepared as an account of work sponsored by an agency of the United States Government. Neither the United States Government nor any agency Thereof, nor any of their employees, makes any warranty, express or implied, or assumes any legal liability or responsibility for the accuracy, completeness, or usefulness of any information, apparatus, product, or process disclosed, or represents that its use would not infringe privately owned rights. Reference herein to any specific commercial product, process, or service by trade name, trademark, manufacturer, or otherwise does not necessarily constitute or imply its endorsement, recommendation, or favoring by the United States Government or any agency thereof. The views and opinions of authors expressed herein do not necessarily state or reflect those of the United States Government or any agency thereof. 


\section{DISCLAIMER}

Portions of this document may be illegible in electronic image products. Images are produced from the best available original document. 


\section{THE USE OF THE PULP AND PAPER INDUSTRY PROCESS MODEL FOR R\&D DECISION MAKING}

David A. Pilati and Richard Rosen

March 1978

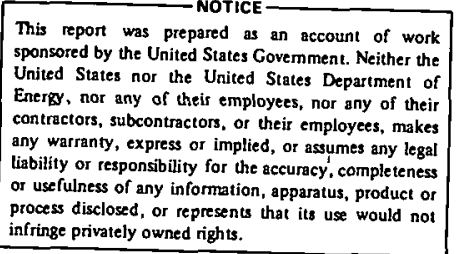

- Prepared for the

DIVISION OF INDUSTRIAL CONSERVATION UNITED STATES DEPARTMENT OF ENERGY

BY THE

ECONOMIC ANALYSIS DIVISION

DEPARTMENT OF ENERGY AND ENVIRONMENT

BROOKHAVEN NATIONAL LABORATORY

UPTON, NEW YORK 11973 
This report was prepared as an account of work sponsored by the United States Government. Neither the United States nor the United States Department of Energy (DOE), nor any of their employees, nor any of their contractors, subcontractors, or their employees, makes any warranty, express or implied, or assumes any legal liability or responsibility for the accuracy, completeness or usefulness of any information, apparatus, product or process disclosed, or represents that its use would not infringe privately owned rights.

Printed in the United States of America

Available from

National Technical Information Service

U.S. Department of Commerce

5285 Port Royal Road

Springfield, VA 22161

Price: Printed Copy $\$ 4.00$; Microfiche $\$ 3.00$

July 1978

410 copies 


\section{ABSTRACT}

A regional pulp and paper industry process model was used to assess the maximal market penetration of new energy conservation technologies for that industry under various energy price assumptions. This linear programming optimization model was used to calculate the systemic impacts on the industry of each technology separately, and as a group. The attractiveness of various cogeneration technologies derived from the model was also evaluated with and without an investment tax credit. These were compared to the market penetration levels estimated in a report prepared by Resource Planning Associates, Inc. The implication of the model runs for R\&D funding decision making within the DOE Division of Industrial Conservation were discussed. 


\section{THIS PAGE}

\section{WAS INTENTIONALLY \\ LEFT BLANK}




\section{CONTENTS}

I. Introduction........................ I

II. Evaluation of New Conservation Technologies...... 2

A. Rapson Closed-Cycle Pulping............. 6

B. Chemical Recovery Systems - Hydropyrolysis and Vapor Recompression.................. 6

C. All New Technologies - Their Systemic Impact.. 9

D. Synergism Between New Technologies.......... 11

III. Evaluation of Thermomechanical Pulping......... 11 -

IV. Evaluation of Lowering Paper Quality.......... 13

V. Evaluation of Cogeneration Potential.......... 13

VI. Implications for R\&D Funding.............. 17 


\section{The Use of the Pulp and Paper Industry Process \\ Model for R\&D Decision Making}

\section{INTRODUCTION}

The National Center for Analysis of Energy Systems at Brookhaven National Laboratory is in the process of developing and managing a set of linear programming models of industrial processes. These models of specific industries contain engineering process and cost data, with emphasis on energy flows, and are designed to select those processes and output levels that minimize the cost of meeting industrial demands specified in physical units. Figure 1 presents a schematic of the general process model inputs, outputs, and sample constraints.

\begin{tabular}{|c|c|c|}
\hline \multicolumn{3}{|c|}{$\begin{array}{l}\text { Figure } 1 \\
\text { ess Model Characteristics }\end{array}$} \\
\hline $\begin{array}{l}\text { INPUTS } \\
\text { - Energy Prices } \\
\text { - Capital Costs } \\
\text { - Existing Capital } \\
\text { Equipment } \\
\text { - Final Demands } \\
\text { - Operating Costs }\end{array}$ & $\begin{array}{l}\text { Process Model: Description of } \\
\text { Industry Structure, Processes } \\
\text { and Technologies at Selected } \\
\text { Level of Detail. Model Chooses } \\
\text { Technologies that Minimize } \\
\text { Production Costs. } \\
\text { CONSTRAINTS } \\
\text { - Availability of Technology } \\
\text { - Total Investment } \\
\text { - Fuel Availability } \\
\text { - Other Resource Availability }\end{array}$ & $\begin{array}{l}\rightarrow \text { OUTPUTS } \\
\text { - Production Costs } \\
\text { - Energy Use by Type } \\
\text { - Investments in Each } \\
\text { Technology } \\
\text { - Capacity of Each } \\
\text { Technology } \\
\text { - Other Resource } \\
\text { Consumption } \\
\text { - Shadow Prices }\end{array}$ \\
\hline
\end{tabular}

This report presents several applications of the pulp and paper industry model developed by $T$. Sparrow and J. Chang at the University of Houston. The results of these analyses were presented to the Division of Industrial Conservation of the Department of Energy during the 1977-78 winter. The relationship of energy to the introduction of new energy conservation technologies, specifically thermomechanical pulping, increased cogeneration, closed-cycle pulping, hydropyrolysis, vapor recompression, and the lowering of paper quality, are presented in Sections II through $V$. The effects on energy use and technology mix of changing relative energy prices between regions and among fuels are also discussed. The implications of these findings for conservation technology R\&D funding are stated in Section VI. 
The pulp and paper model is a four-region model; its major elements are outlined in Figure 2. Three fiber types are used in each of the four regions to produce one of eight pulp types. These pulps are further processed (e.g., bleached) to provide the inputs required for eight final product types. By starting with existing capacity in a particular year, this static one period model calculates the resource requirements, including new capacity, to meet a specified final demand at some specified future time. Existing capacity can also be retrofitted with certain technological options.

\begin{tabular}{|c|c|c|}
\hline \multicolumn{3}{|c|}{ Figure 2} \\
\hline Regions & Fibers & Pulps \\
\hline $\begin{array}{l}\text { 1-North East } \\
\text { 2-North Central } \\
\text { 3-South } \\
\text { 4-West }\end{array}$ & $\begin{array}{l}\text { 1-Roundwood } \\
\text { 2-Sawni11 residue } \\
\text { 3-Waste paper }\end{array}$ & $\begin{array}{l}\text { 1-Groundwood } \\
\text { 2-Semi-chemical } \\
\text { 3-Sulfate (kraft) } \\
\text { 4-Sulf1te } \\
\text { 5-Paper stock } \\
\text { 6-Defibrated/exploded } \\
\text { 7-Rapson } \\
\text { 8-Thermomechanical }\end{array}$ \\
\hline Processed Pulps & . & Papers \\
\hline $\begin{array}{l}\text { 1-Groundwood } \\
\text { 2-Semi-chemical } \\
\text { 3-Unbleached kraft/Rapson } \\
\text { 4-Unbleached sulfite and sem } \\
\text { bleached kraft } \\
\text { 5-Paper stock } \\
\text { 6-Defibrated/exploded } \\
\text { 7-Bleached chemical (sulfite } \\
\text { sulfate, Rapson) }\end{array}$ & mi - & $\begin{array}{l}\text { 1-Newsprint and uncoated ground- } \\
\text { wood } \\
\text { 2-Writing/printing \& related } \\
\text { 3-Sanitary } \\
\text { 4-Packaging and industrial } \\
\text { converting } \\
\text { 5-Container board } \\
\text { 6-Boxboard } \\
\text { 7-Construction paper and paper- } \\
\quad \text { board } \\
\text { 8-Dissolving pulp (input to rayor }\end{array}$ \\
\hline
\end{tabular}

\section{EVALUATION OF NEW CONSERVATION TECHNOLOGIES}

Industry process models can be used to evaluate the overall system-wide impacts of introducing a new technology into an industry. As linear programming models, they are likely to indicate the maximum likely (the rational upper limit) technology penetration rates that would be consistent with profit maximization. To demonstrate this capability, several new conservation technologies proposed for the pulp and paper industry were investigated for their potential energy savings, and these results were compared with an engineering 
calculation of the savings. The conserving technologies studied included the Rapson closed-cycle kraft pulping process and two new black liquor recovery sys tems, hydropyrolys is and vapor recompression.

The energy savings calculated from the systems perspective can be given as follows:

$$
\begin{gathered}
\text { System energy savings = Engineering energy savings }+ \\
\text { Induced savings }
\end{gathered}
$$

To make the system vs. engineering savings comparable, we have used the process models to predict the penetration rates of the new technology for use in the engineering calculation. If we had done a piece-meal or first-order incremental investment analysis based on the cost/benefit of the new technology alone, without using the process model, the level of market penetration itself generally would have come out very differently. Therefore, in this report,

\section{Systems energy savings = (Engineering energy savings/unit)}

$x$ (Units predicted by systems analysis) + Induced savings

The engineering savings per unit included both "first-order" effects and readily foreseeable "second-order" perturbations to the energy consumption that were caused by the first-order changes. The induced savings, then, are the higher-order energy use perturbations that only the model can readily take account of.

There are at least two ways in which induced savings can arise. First, the activity mix can change within regions. For example, pulping activity $A$ may suddenly become attractive enough to substitute for a more energy-intensive pulping activity $B$, when the investment is made in technology $C$. Second, regional mix changes may decrease (or increase) energy consumption. For example, a change in regional pulp production may cause both a decrease in interregional market pulp sales and concomitant pulp-drying energy savings and a change in the energy requirements for the new pulp mix.

A11 the system energy savings runs are for the year 1990. Product demands are predicated on an assumed $-2 \%$ per year growth rate for each final product. Energy prices assumed are prices based on uniform regional increases of the 1975 energy prices, and hereafter will be labeled "BNL" prices. Table 1 gives the assumed prices and explains how they were derived from their respective 1975 values.

Figure 3 describes in more detail the sulfate pulping and bleaching system which is the subsystem affected by the new technologies evaluated here. Figure 3, then, is the expansion of the pulping-bleaching box that appears in Figure 4. With the addition of the Rapson closed-cycle process there are two means of producing kraft pulp. The closed-cycle kraft pulp either can be used unbleached or can be fully bleached. Figure 3 depicts three alternative chemical recovery systems: conventional, hydropyrolysis, and vapor recompressiion. All the new technology changes are described in this subsystem diagram. 


\section{Table 1}

\section{Regional Delivered Energy Prices for BNL Price Case}

\begin{tabular}{|c|c|c|c|c|}
\hline & \multicolumn{4}{|c|}{1990 Energy Prices* (1975 Dollars $/ 10^{6}$ Btu Delivered) } \\
\hline & Natural gas & $0 i 1$ & Coal & Electricity \\
\hline $\begin{array}{l}\text { North East } \\
\text { North Central } \\
\text { South } \\
\text { West }\end{array}$ & $\begin{array}{l}2.94 \\
1.64 \\
1.56 \\
1.52\end{array}$ & $\begin{array}{l}2.10 \\
2.40 \\
2.52 \\
2.21\end{array}$ & $\begin{array}{l}1.86 \\
0.88 \\
0.88 \\
1.80\end{array}$ & $\begin{array}{r}13.83 \\
9.89 \\
9.02 \\
7.52\end{array}$ \\
\hline
\end{tabular}

Figure 3

Sulfate Pulping/Bleaching System

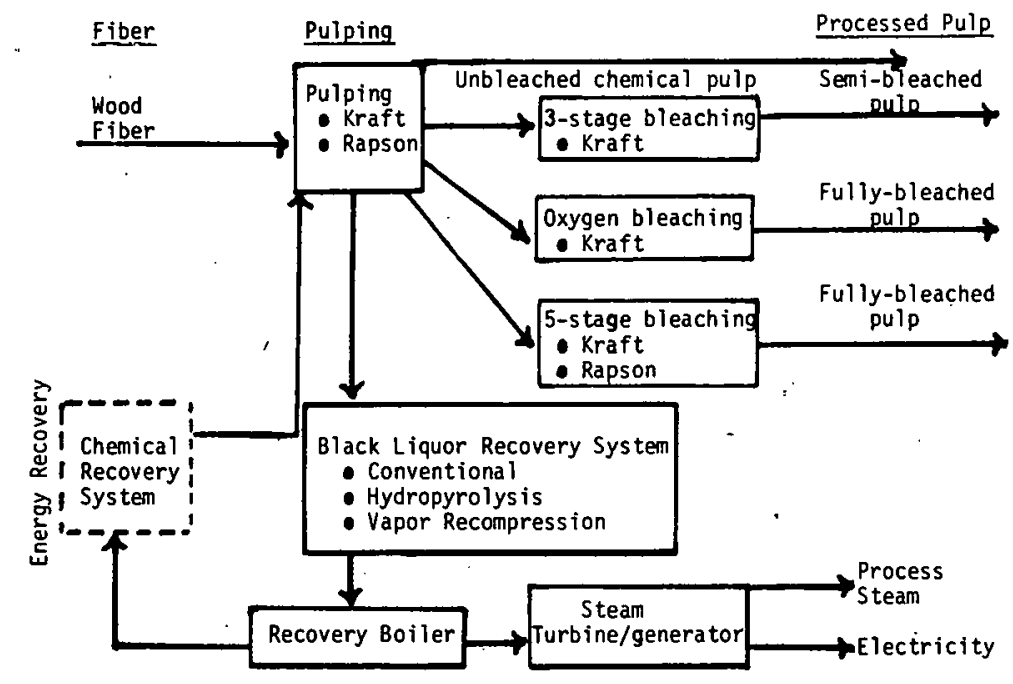


Figure 4

Flow Chart of Paper Industry

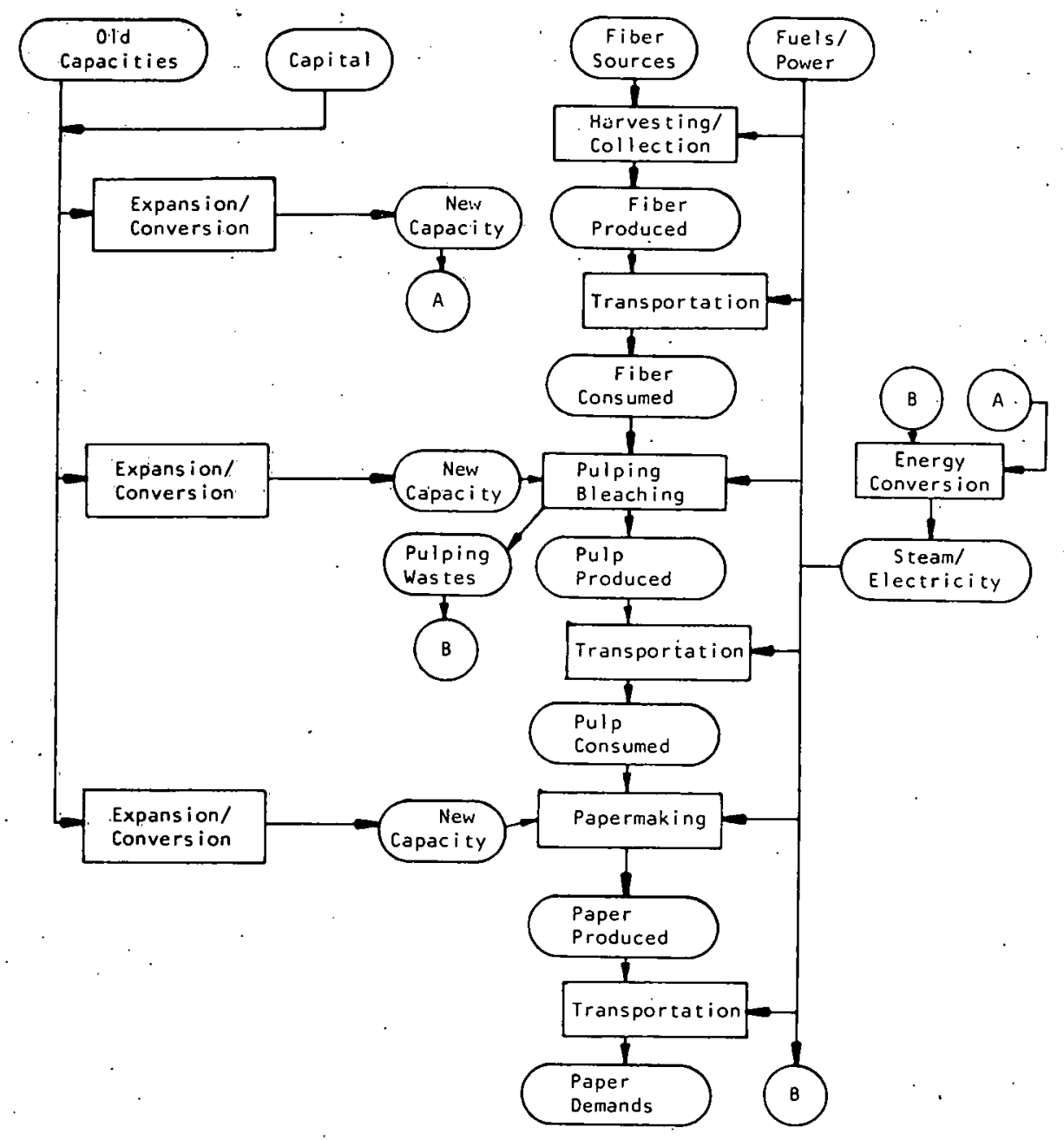




\section{A. Rapson Closed-cycle Pulping}

One proposed modification to the popular kraft pulping process is the Rapson closed-cycle process, which is merely a:closed-cycle kraft pulping process. For systematic comparison of these alternative pulping processes the fiber production, black liquor recovery, bleaching," and steam generation processes have to be analyzed in addition to the pulping processes themselves. Table 2 gives the detailed energy consumption differences for the two bleached pulp alternatives. In the aggregate, the closed-cycle scheme saves in fiber and all forms of purchased energy.

As shown in Table 3, the energy savings calculated by the engineering and systems approaches are quite close. However, this is somewhat fortuitous. The closed-cycle process is a major steam saver compared with the standard kraft process. The steam savings reduces the use of coal for providing process steam and cogenerated electricity. Hence, electricity purchases increase to counteract the loss of cogenerated electricity in those regions where electricity is relatively inexpensive. However, where electricity is relatively expensive, the reduction in coal cogenerated electricity is compensated for by increasing the use of oil-fired gas turbines. Therefore, coal use decreases while the demand for oil increases. Note, however, that in this case, as with several of the other technologies evaluated, the increase in oil use compared with energy saved is very smal1, well within the error limits on the energy coefficients in the model. Also, the levels of oil usage that result are much less than present-day usage by the industry, as can be seen by comparing Table 7 with the 1974 value for 011 of $455 \times 10^{12}$ Btu.

Besides substitution of standard kraft pulping by the Rapson process, there is also some displacement of sulfite chemical pulp. This is a minor effect as far as energy use is concerned but not in the analys is of new recovery systems that follows.

\section{B. 'Chemical Recovery Systems - Hydropyrolys is and Vapor Recompression}

As shown in Figure 3, the hydropyrolysis and vapor recompression chemical recovery systems can substitute for the conventional system. To examine the energy savings potential of each new recovery system, each was allowed to compete with the conventional system alone.

Table 4 shows the engineering and systems energy savings that would occur in 1990 if hydropyrolysis were introduced as a chemical recovery system. Unlike the Rapson comparison, there is a significant induced savings that is calculated by the process model but does not appear in the engineering approach. Analysis of the systems result shows that two competing effects combine to produce the high induced savings (engineering savings $=34 \times 10^{12} \mathrm{Btu}$; induced savings $\left.=71 \times 10^{12} \mathrm{Btu}\right)$. First, kraft pulp production using the hydropyrolysis recovery system appears to compete more favorably with sulfite pulp. Some sulfite pulp is therefore substituted for by the kraft pulp which results in significant coal savings. On the other hand, there is an increase in interregional market pulp production as the regional mix of pulp production changes. 
Table 2

Bleached Sulfate Energy. Requirements (per ton bleached pulp)

\begin{tabular}{|c|c|c|c|}
\hline Process & Kraft & Rapson & Kraft/Rapson savings \\
\hline $\begin{array}{l}\text { Feeds tock: } \\
\text { Fiber }\left(10^{6} \text { Btu) }\right.\end{array}$ & 42.78 & 40.70 & +2.08 \\
\hline $\begin{array}{l}\text { Bleaching: } \\
\text { Electricity (kWh) } \\
\text { Process steam (1b) }\end{array}$ & $\begin{array}{r}117 \\
8642\end{array}$ & $\begin{array}{l}108 \\
890\end{array}$ & $\begin{array}{r}+9 \\
+7752\end{array}$ \\
\hline $\begin{array}{l}\text { Pulping: } \\
\text { Electricity (kWh) } \\
\text { Process steam (1b) } \\
0 i 1\left(10^{6} \text { Btu) }\right.\end{array}$ & $\begin{array}{c}317 \\
7068 \\
2.3\end{array}$ & $\begin{array}{r}322 \\
8882 \\
2.2\end{array}$ & $\begin{array}{r}-5 \\
-1814 \\
+0.1\end{array}$ \\
\hline $\begin{array}{l}\text { Black liquor recovery: } \\
\text { Electricity (kWh) } \\
\text { Process steam (1b) }\end{array}$ & $\begin{array}{r}188 \\
5281\end{array}$ & $\begin{array}{r}196 \\
5495\end{array}$ & $\begin{array}{r}-8 \\
-214\end{array}$ \\
\hline $\begin{array}{l}\text { Energy Recovery } \\
\text { Steam/electric generation: } \\
\text { Electricity (kWh) } \\
\text { Process steam (1b) }\end{array}$ & $\begin{array}{r}-551 \\
-.13439\end{array}$ & $\begin{array}{r}-573 \\
-13980\end{array}$ & $\begin{array}{r}+22 \\
+541\end{array}$ \\
\hline \multicolumn{4}{|c|}{ Net savings (per ton bleached pulp) } \\
\hline $\begin{array}{l}\text { Fiber: } 2.08 \times 10^{6} \mathrm{Btu} \\
\text { Electricity: } 18 \mathrm{kWh}\end{array}$ & & $\begin{array}{l}\text { Process steam: } \\
011: \quad 10^{5} \text { B tu }\end{array}$ & $6265 \mathrm{lb}$ \\
\hline
\end{tabular}

Table 3

Rapson: Engineering Versus System Energy Savings

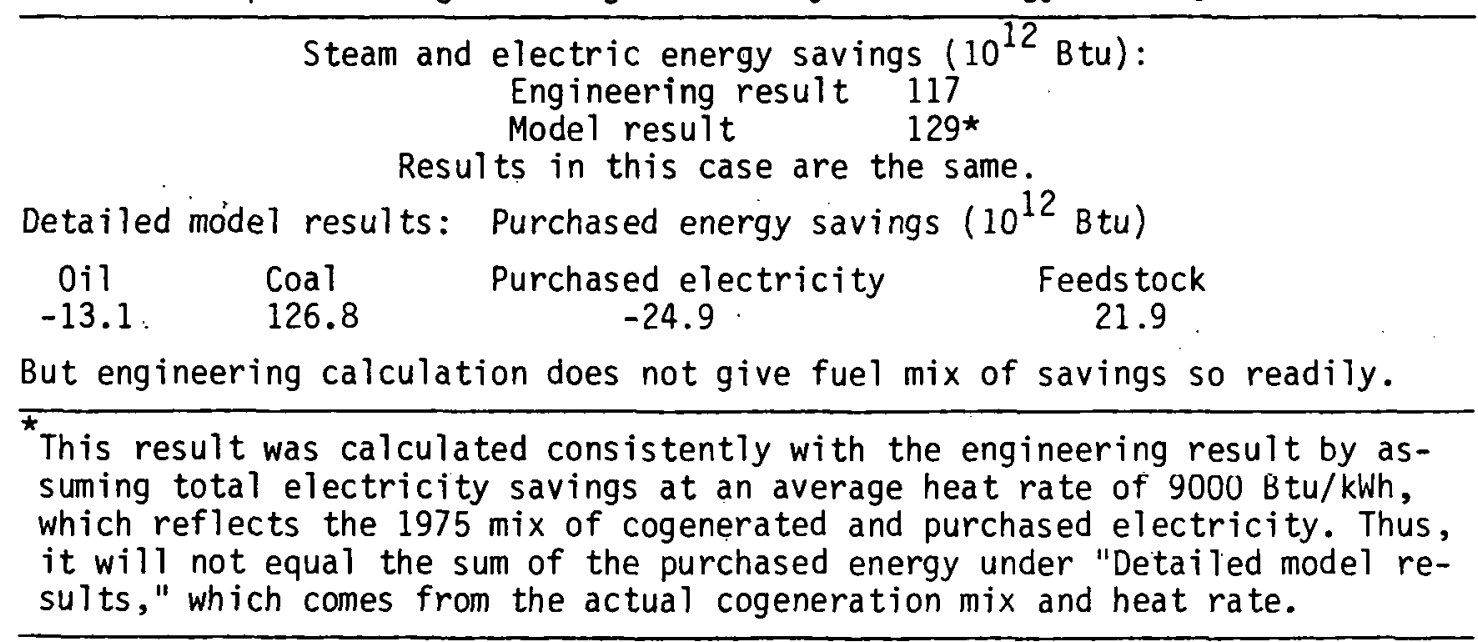


Table 4

Hydropyrolysis: Engineering Versus System Energy Savings

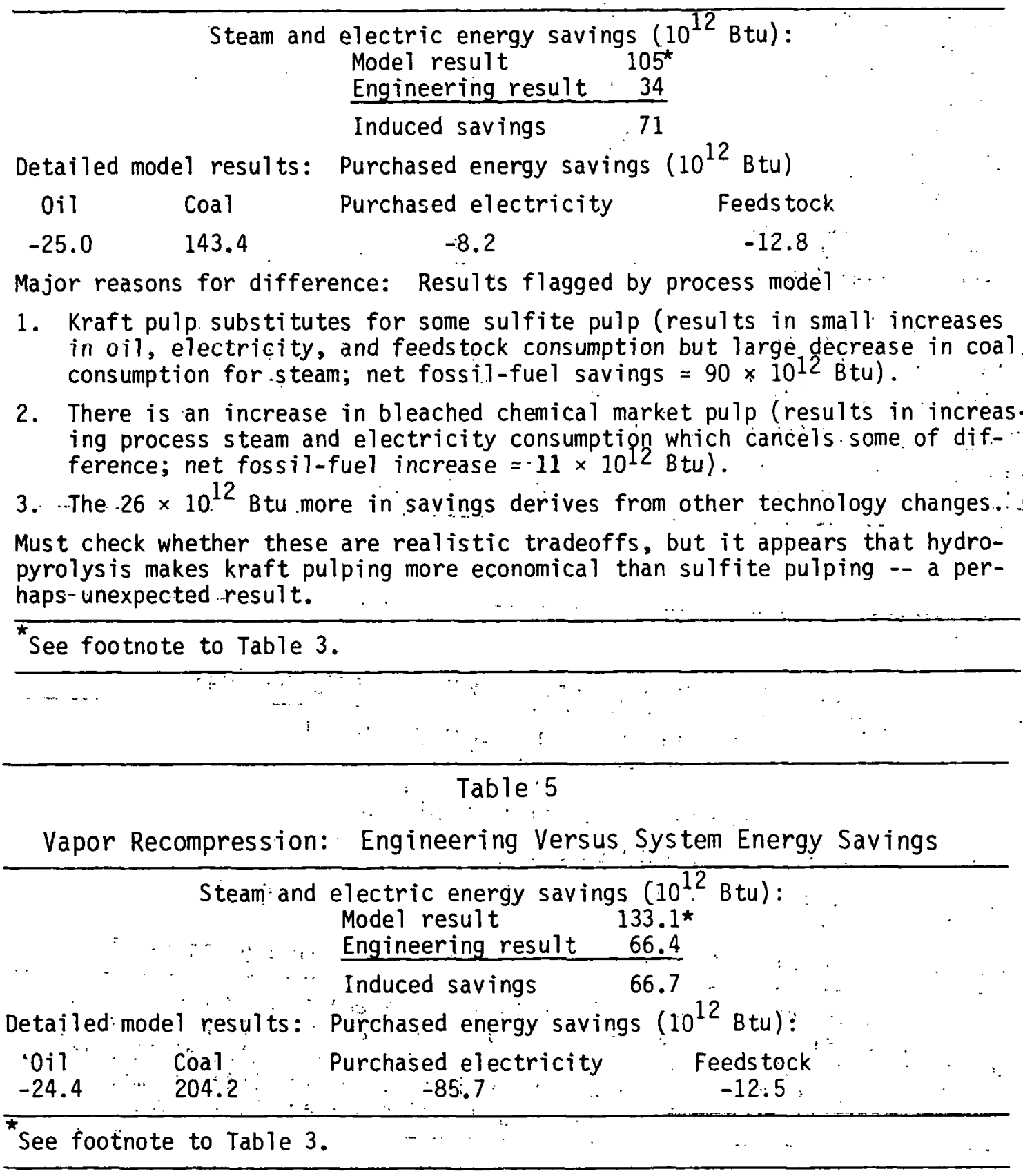


This phenomenon has the effect of somewhat increasing energy use because of the additional pulp-drying step required in transportation. However, the overall effect is a significant amount of induced savings.

Table 5 describes the engineering and systems energy savings that occur in 1990 if the vapor recompression recovery system is allowed to compete with the conventional system. The results are similar to those for the hydropyrolysis analysis. Total system savings are more than twice the engineering calculations. The reasons for the induced savings are also identical to those for hydropyrolysis; kraft pulp substitutes for some sulfite pulp, and the energy savings dominate the additional energy requirements of the increased market pulp.

As shown in Table 6, vapor recompression is a very electricity-intensive chemical recovery system. Therefore, actual market penetration will depend strongly on the price of electricity. To demonstrate this effect, several analyses were made with electricity prices perturbed about the actual energy price assumed above. As shown in Figure 5, if actual electricity prices were $50 \%$ above those assumed, the conventional recovery systems would totally dominate the market. However, if our assumed electricity prices were reduced by $25 \%$, vapor recompression penetration would tend to increase its share of the market by a factor of 2.5. Clearly, then, our general results are very dependent on the energy price scenarios assumed.

Table 6

Comparison of Energy Use Characteristics of Chemical Recovery Systems

\begin{tabular}{lcc}
\hline & $\begin{array}{c}\text { Energy Use (per lb of high pressure steam production) } \\
\text { Process Steam (1b) }\end{array}$ & Electricity (kWh) \\
\hline Conventional & 0.393 & 0.014 \\
Hydropyrolysis & 0.261 & 0.009 \\
Vapor recompression & - & 0.029 \\
\hline
\end{tabular}

Besides comparing new technologies separately, it is also possible to compare all the new technologies with the existing ones by using the systems model approach. Table 7 presents detailed 1990 fuel use projections both with and without all the new technologies and for two different sets of regional fuel prices. The two price assumptions are labeled BNL and NEP, corresponding to the prices given in Tables 1 and 8 , respectively. The BNL prices are based on uniform regional price increases over 1975 values. The NEP prices are based on the FEA PIES model results for implementation of the National Energy Plan. For both assumptions about technologies, the NEP price schedule results in lower energy use than the BNL schedule. For practical purposes, the NEP prices can be considered a high-price scenario compared with the BNL prices. 
Figure 5

Penetration of Vapor Recompression as a Function of Electricity Prices

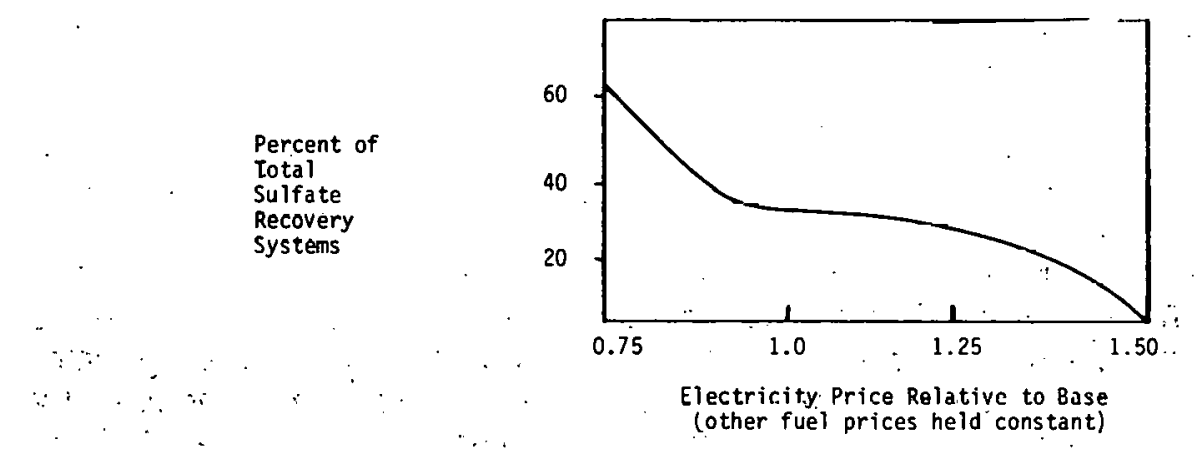

Table 7 .

Sensitivity of Results to Regional Fuel Price Structure Comparison of NEP and BNL Price Projections $i$.

\begin{tabular}{|c|c|c|c|c|c|c|}
\hline \multirow[t]{2}{*}{. } & \multirow[b]{2}{*}{ י } & \multicolumn{2}{|c|}{$\cdot$} & \multicolumn{2}{|c|}{ Energy use $\left(10^{12} \mathrm{Btu}\right)$} & \multirow[b]{2}{*}{$\begin{array}{l}\text { Net purch. } \\
\text { energy }\end{array}$} \\
\hline & & Gas & $0 i 1$ & Coal & $\begin{array}{c}\text { Purch. elect. }{ }^{\star} \\
\text { (\% purch.) }\end{array}$ & \\
\hline \multicolumn{7}{|c|}{ No new technologies } \\
\hline NE & 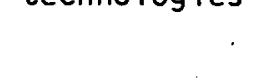 & $\begin{array}{l}15.3 \\
68.1\end{array}$ & $\begin{array}{l}61.4 \\
58.8\end{array}$ & $\begin{array}{r}865.1 \\
1339.0\end{array}$ & $\begin{array}{r}188.0(22) \\
77.0 .(10)\end{array}$ & $\begin{array}{l}1080.0 \\
1241.0\end{array}$ \\
\hline \multicolumn{7}{|c|}{ All new technologies } \\
\hline $\begin{array}{l}\mathrm{NE} \\
\mathrm{BA}\end{array}$ & $\because$ & $\begin{array}{l}15.3 \\
68.1\end{array}$ & $\begin{array}{l}82.0 \\
84.4\end{array}$ & $\begin{array}{l}587.3 \\
973: 2\end{array}$ & $\begin{array}{r}226.0(27) \\
84.0(12)\end{array}$ & $\begin{array}{r}873.0(-19 \%) \\
1100.0(-13 \%)\end{array}$ \\
\hline
\end{tabular}

*Purchased electricity valued at heat rate. 
Table 8

National Energy Plan Regional Energy Prices*

\begin{tabular}{lccccc}
\hline & \multicolumn{1}{c}{1985 NEP Energy } & Prices & $(1975$ & Dol ? ars $/ 10^{6}$ & Btu Delivered $)$ \\
\cline { 2 - 5 } & Natural gas & 011 & Coal & Electricity \\
\hline North East & 2.85 & 3.08 & 1.53 & 10.94 \\
North Central & 3.20 & 2.87 & 1.59 & 8.15 \\
South & 3.23 & 3.20 & 1.20 & 6.61 \\
West & 2.85 & 3.20 & 1.48 & 5.54 \\
\hline
\end{tabular}

*From Federal Energy Administration, Project Independence Evaluation System model.

For both price schedules there is a substantial decrease in overall purchased energy ( $13 \%$ for BNL and 19\% for NEP) given the new technologies. In both cases the new technologies reduce coal use while increasing oil and purchased electricity use. Much of the increased purchase of electricity is due to decreased cogeneration as the total amount of process steam is reduced when the new technologies are employed, a perhaps counter-intuitive result which will be explored.more fully below.

\section{Synergism Between New Technologies}

During the analysis of new technology penetration it was found that occasionaliy the introduction of one new technology caused an increased market penetration for another new technology. This synergistic effect is demonstrated in Figure 6 , where the results of constraining the penetration of hydropyrolysis below its optimal value and the concomitant effects on Rapson penetration are given. Allowing hydropyrolys is to be used causes a $50 \%$ increase in the use of the closed-cycle Rapson process. More importantiy, most of this increase is achieved if hydropyrolysis achieves only $40 \%$ of its potential market share. For the BNL prices assumed, low penetration of hydropyrolys is has a marked effect on the total penetration of the Rapson pulping process.

Once again, such results are highly dependent on the precise regional energy prices assumed. Under the NEP price assumptions, Rapson penetration is not affected by hydropyrolysis penetration, but the closed-cycle pulping process is sensitive to the amount of vapor recompression introduced (Table 9).

\section{EVALUATION OF THERMOMECHANICAL PULPING}

Thermomechanical pulping is a currently existing technique that is projected to increase rapidly in importance in the near future. The process model was used to evaluate the effects on energy use of an increase in the thermomechanical market share. The results (Table 10) show that net purchased energy 


\section{Figure 6}

Rapson Penetration as a Function of Hydropyrolys is Penetration

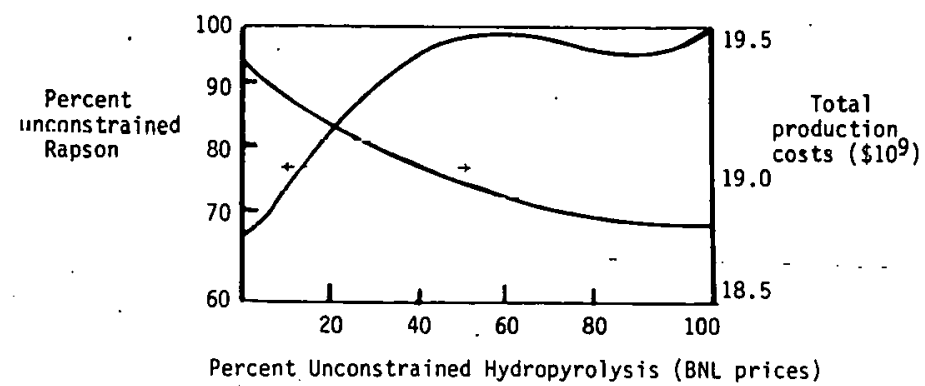

Table 9

Rapson Production as a Function of New Recovery System Penetration

NEP Prices

Hydropyrolys is Penetration (\%) Rapson Production ( $10^{6}$ tons)

$100 *$

0

Vapor Recompression Penetration (\%)

100 *

0

19.0

Rapson Production ( $10^{6}$ tons)

19.0

15.7

BNL Prices

Hydropyrolys is Penetration (\%) Rapson Production ( $10^{6}$ tons)

$100 *$

0

18.5

12.2

$\star 100 \%$ of unconstrained level. 


\section{Table 10}

Pulp and Paper Energy Use Characteristics With and Without Thermomechanical Pulping (NEP Prices, 1990)

\begin{tabular}{lccccc}
\hline & \multicolumn{4}{c}{ Energy $\left(10^{12}\right.$ Btu) } \\
\cline { 2 - 6 } & Nat. gas & 0 il & Coal & Elect. used* & $\begin{array}{c}\text { Net Purch. } \\
\text { energy** }\end{array}$ \\
\hline Al1 technologies & 15.3 & 81.9 & 587.3 & 280.4 & 873.0 \\
No thermomech. pulping 15.3 & 82.3 & 590.7 & 274.7 & 856.0 \\
\hline
\end{tabular}

*Electricity converted at $3413 \mathrm{Btu} / \mathrm{kWh}$.

$\star \star$ Purchased electricity converted at 10,500 Btu/kWh.

increascs compared with the case in which no thermomechanical pulping is included. Thermomechanical pulp substitutes primarily for groundwood pulp and requires more electricity; this is reflected in the systems results of Table 10. Thermomechanical pulping has higher capital costs than groundwood but lower operating costs; overa11, its use reduces dollar costs but increases energy consumption. The process model, then, could be used to find the regional electricity prices at which thermomechanical pulping would no longer be costeffective and would therefore not be used by industry.

\section{EVALUATION OF LOWERING PAPER QUALITY}

Lowering the quality of paper reduces the amount of bleached chemical pulps required, and many people believe that this would reduce the energy requirements for the pulp and paper industry. The pulp and paper process model was used to evaluate the energy effects of a $10 \%$ decrease in bleached pulp requirements for writing papers only, which would decrease the General. Electric (G.E.) brightness by about $10 \%$ from base paper quality. The results of this analysis are given in Table 11. Although total energy use including feedstocks declines, use of purchased fuels actually increases. The bleached pulp savings were effected through reducing the amount of chemical pulp in writing paper by increasing the amounts of other pulps in it (i.e., groundwood, semi-chemical, unbleached chemical, and paper stock). Qualitatively similar results are obtained if semibleached kraft pulp or unbleached sulfite pulp is substituted for fully bleached kraft pulp. A $20 \%$ reduction in bleached chemical pulp in writing papers causes similar, but greater, changes in energy use.

\section{EVALUATION OF THE COGENERATION POTENTIAL}

Resource Planning Associates, Inc. (RPA), in a report recently prepared for FEA, The Potential for Cogeneration Development in Six Major Industries by 1985, examined the types of cogeneration facilities and the extent of market 
Table 11

Energy . Effects of Reducing Paper Quality (NEP. Prices)

$\%$ Change

\begin{tabular}{lc}
\hline Electricity use & $+0.01 \%$ \\
Electricity sold & $+0.6 \%$ \\
Gas use & 0 \\
Oil use & $-1.5 \%$ \\
Coal use & $+1.5 \%$ \\
Purchased fuels & $+0.9 \%$ \\
Recovered energy & $-1.8 \%$ \\
Total energy (incld. feedstocks) & $-0.7 \%$ \\
\hline
\end{tabular}

Table 12

RPA Fuel Prices for $1985, * 1975$. Dollars $/ 10^{6}$ Btu (same for all regions)

\begin{tabular}{lcccc}
\hline Gas & $0 i 1$ & Coal & Electricity \\
\hline 2.40 & 2.20 & 1.23 & 7.32 \\
\hline $\begin{array}{l}\text { * Since our total product demand for } 1990 \text { was within } 6 \% \text { of the RPA } 1985 \\
\text { product demand, these prices should be compared with the } 1990 \text { fuel } \\
\text { prices cited in Table } 1 .\end{array}$ \\
\hline
\end{tabular}

penetration for the paper industry both with and without a set of investment incentives. Their estimates were made with the uniform national fuel prices given in Table 12, which are generally lower than the NEP price scenario in Table 8. The investment tax incentives that RPA applied to cogeneration investment only consisted of a change from $10 \%$ to $30 \%$ for investment tax credit, and accelerated depreciation from 25 to 12 years. Since investment in our pulp and paper industry process model was charged to one year's production at a fixed charge rate (FCR) of $15 \%$, we calculate that these investment tax changes would reduce the $F C R$ for cogeneration equipment to $210 \%$. Finally, our previous model analysis of new conservation technologies (described above) included high efficiency modern steam turbines with an output of $75 \mathrm{kWh}$ per $10^{3} 1 \mathrm{~b}$ process steam produced as well as intermediate efficiency turbines of 41 and $45 \mathrm{kWh} / 10^{3}$ 16 steam for oil and new steam turbines respectively. However, since RPA chose to limit new steam turbines to $41 \mathrm{kWh} / 10^{3} \mathrm{ib}$ steam, we constrained our technologies similarly for some of the runs. Gas turbines were included in our model and in the RPA analysis, and diesel cogeneration was included in neither.

We made three sets of comparisons with the RPA report:

1. We varied fuel prices - NEP vs. RPA prices with technologies fixed.

2. We varied the FCR from $15 \%$ to $10 \%$ to mimic the higher investment incentives for cogeneration technologies only, for each set of fuel prices. 
3. We varied the steam turbine technology to allow the high efficiency turbines to enter our model solution for the NEP prices.

The results of these runs are shown in Table 13, with the steam capacities of several new and cogeneration technologies listed at the bottom. It is obvious that the higher NEP prices do lead to lower net purchased energy consumed in all cases, as expected. One minor but interesting result is that, in the NEP high efficiency case, the reduction of the FCR causes cogenerated electricity to become so cheap that vapor recompression technology (VCR) is

\begin{tabular}{|c|c|c|c|c|c|c|}
\hline \multicolumn{7}{|c|}{$\begin{array}{l}\text { Table } 13 \\
\text { Cogeneration Results (Energ }\end{array}$} \\
\hline & $\frac{\overline{\text { High }}}{15 \% \bar{a}}$ & $\frac{\text { NEP }}{\frac{\text { ciency }}{10 \%}}$ & $\frac{\text { prices }}{\frac{\text { RPA eff }}{15 \%}}$ & $\frac{i \text { iciency }}{10 \%}$ & \multicolumn{2}{|c|}{$\frac{\text { RPA prices }}{\text { RPA efficiency }}$} \\
\hline Invest. $\left(\$ 10^{9}\right)$ & 22.3 & 21.2 & 21.3 & 21.1 & 21.6 & 20.5 \\
\hline $\begin{array}{l}\text { Gas } \\
0 \text { il } \\
\text { Coal } \\
\text { Cogen. elect. } \\
\text { Purch. elect. } \\
\text { Sold elect. } \\
\text { Net pur. energy }\end{array}$ & $\begin{array}{r}15.2 \\
82.0 \\
585.0 \\
217.0 \\
75.0 \\
12.0 \\
873.0\end{array}$ & $\begin{array}{r}15.2 \\
82.0 \\
658.0 \\
227.0 \\
68.0 \\
14.0 \\
921.0\end{array}$ & $\begin{array}{r}15.2 \\
100.0 \\
254.0 \\
109.0 \\
188.0 \\
0.0 \\
933.0\end{array}$ & $\begin{array}{r}15.2 \\
101.0 \\
354.0 \\
118.0 \\
169.0 \\
0.0 \\
978.0\end{array}$ & $\begin{array}{r}15.2 \\
523.0 \\
455.0 \\
240.0 \\
17.0 \\
0.0 \\
1045.0\end{array}$ & $\begin{array}{r}15.2 \\
328.0 \\
831.0 \\
221.0 \\
15.0 \\
0.0 \\
1221.0\end{array}$ \\
\hline \multicolumn{7}{|c|}{ Steam capacities $\left(10^{9} 1 \mathrm{~b}\right.$ steam) } \\
\hline $\begin{array}{l}H^{H P R}{ }^{C} \\
\text { VCR } \\
\text { OId S.T. } \\
\text { New S.T. } \\
\text { High eff. S.T. } \\
\text { G.T. (oi i) }\end{array}$ & $\begin{array}{r}190.0 \\
54.0 \\
28.0 \\
39.0 \\
808.0 \\
0.0\end{array}$ & $\begin{array}{r}27.0 \\
210.0 \\
28.0 \\
46.0 \\
890.0 \\
0.0\end{array}$ & $\begin{array}{c}189.0 \\
54.0 \\
539.0^{d} \\
208.0 \\
0.0 \\
6.0\end{array}$ & $\begin{array}{c}222.0 \\
22.0 \\
539.0 \mathrm{~d} \\
272.0 \\
0.0 \\
6.0\end{array}$ & $\begin{array}{c}243.0 \\
0.0 \mathrm{~d} \\
539.0 \mathrm{~d} \\
235.0 \\
0.0 \\
152.0\end{array}$ & $\begin{array}{r}232.0 \\
0.0 \\
539.0^{d} \\
571.0 \\
0.0 \\
85.0\end{array}$ \\
\hline \multicolumn{7}{|c|}{ 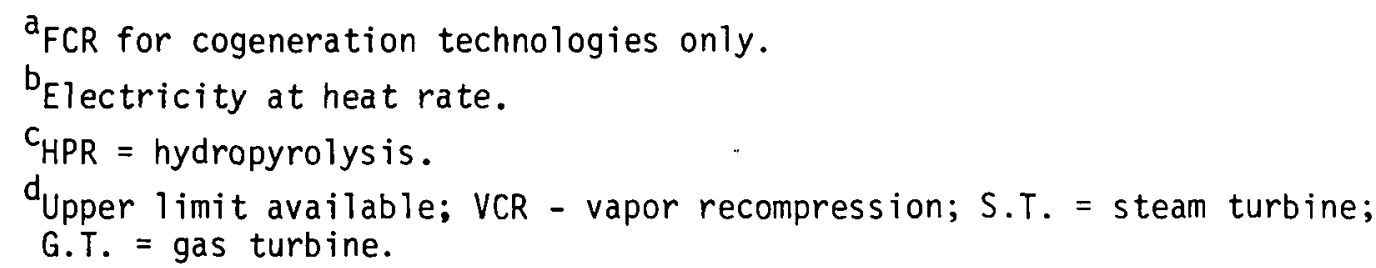 } \\
\hline
\end{tabular}

favored over hydropyrolysis. Furthermore, in this case the high efficiency steam turbines are strongly demanded in all regions except the West with a shadow price of $\$ 0.60 / 10^{6}$ Btu process steam produced. In the West, purchased electricity is too cheap for cogeneration to be worthwhile. When high efficiency steam turbines are excluded in the NEP case, the cost of cogenerated electricity goes up and much more electricity is purchased regardless of the FCR. 
For the two RPA efficiency cases, the reduction in FCR leads to increased investment in new steam turbines regardless of fuel price structure. This leads to a decrease in the use of gas turbines (which have a much higher electricity output ratio) and thus actually causes a net decrease in the amount of electricity cogenerated. Even in the NEP case, the increase in the level of electricity cogenerated due to tax incentives was very small indeed $(\sim 8 \%)$.

The major counterintuitive result for both RPA and NEP prices is the change in net purchased energy by the industry due to the lower FCR: it increases by $5 \%$ and $17 \%$, respectively! The details of the process model provide a ready explanation for this effect. By reducing the FCR for cogeneration only we have, in essence, overemphasized investment in this technology relative to other conservation technologies. For example, the increase in investment in cogeneration decreases the investment in the Rapson closedcycle pulping process. This process would have saved steam, but it was not cost effective because the lower FCR made cogenerated steam cheaper. The clear implication of this result is that, when considering tax incentives for conservation, the government must be careful not to cause investment to become skewed in such a way that total energy consumption will not be minimized. This result came about only when cogeneration had already reached a certain level of market penetration; thus, tax incentives designed to promote a particular conservation technology may still have a role in helping that technology achieve some minimum level of market penetration.

In the RPA report ( $P . D-9)$ it was estimated that cogeneration would provide about $38 \times 10^{9} \mathrm{kWh}$ of electricity and 0.89 quads of process steam for the paper and pulp industry by 1985 with their fuel price structure. This would be generated $98 \%$ by steam turbines and $2 \%$ by gas turbines, and the increase in the cogeneration of electrigity due to changing the tax laws in the way described above would be $6.7 \times 10^{9} \mathrm{kWh}$. In contrast, using the process model we find that, without any non-price constraigts imposed on oil used for gas turbine cogeneration, in the RPA case $\sim 70 \times 10^{9} \mathrm{kWh}$ of electricity and 0.93 quads of process steam would be the maximum cost-effective level of cogeneration (even with a product production level 6\% below RPA's), and that this would be produced $30 \%$ by steam turbines and $70 \%$ by gas turbines. In this case, we also found that the electricity cogenerated would actually decrease because of the decrease in FCR. The cogenerated process steam increase due to the $\triangle F C R$ was $29 \%$ for our model run for their case, whereas RPA estimated $17 \%$.

Presumably some of the difference in these results for electricity is accounted for by RPA's ability to consider the actual distribution of the electric to steam ratio of individual plants in arriving at their estimates, but, since their methodology is not described, we cannot be sure of this. Even so, it is unlikely that only $2 \%$ gas turbine penetration would be most cost effective for the industry. For, if many plants have lower electric/ steam requirements than average, justifying more steam turbines than our model predicts, many must have higher electric/steam ratios, justifying more gas turbines than average. 
Probably, however, most of the difference between the BNL and RPA results can be explained by the presence in our model of many other conservation technologies, which have the net effect of increasing the electric/steam ratio by conserving more steam and thus making gas turbines a better match for this future electric/steam ratio. This illustrates an important point that must always be taken into account when making an engineering as opposed to a systems calculation: one must consider concurrent introduction of other new technologies likely to be utilized by the given future date. This is difficult without a computerized process model of the industry.

\section{IMPLICATIONS FOR R\&D FUNDING}

The role of linear programing process models to assist in funding decisions should grow in the future. Once a process model is constructed, it is very flexible and easy to use. Counterintuitive results do not have to be taken on faith but can be traced through the detailed process structure of the industry to determine just why they occurred. The insight gained through this process is invaluable. Because these models also include relevant economic parameters, they can be used to assess the impact of many kinds of policy options. The assessments can be used to evaluate both the systematic effects of the policy and the relative ability of policy vs. technology to effect the desired goal. It is also extremely easy to use this kind of model to perform sensitivity analyses on any of the myriad parameters that are contained within it.

Specifically, in performing the technological analyses described above for the pulp and paper industry the following conclusions emerge for R\&D decision making:

1. Potential new technologies should be evaluated with use of future energy prices in which there is the highest confidence as well as other price scenarios. Since the potential of a new technology depends on the regiona? energy prices assumed, this procedure allows targeting of those technologies that appear favorable under all likely ranges of future prices. Since there would be little risk to the industry in developing these technologies, they should probably not receive government R\&D funding. Those technologies that appear profitable only under certain energy price scenarios would be candidates for such funding because of the additional risk.

2. Potential energy savings calculated by using engineering approaches may be incorrect since they do not include system savings. Therefore, new technologies should be evaluated for system-wide savings. Similarly, the cost to the industry of a new technology cannot be derived by merely considering the incremental costs of that technology in an isolated fashion. Its market penetration will cause other costs to the industry to realign in such a way that total cost is minimized. This also means that the incremental corporate tax rate for a technology could be far from $48 \%$, for it depends on how net depreciation, cash flow, and investment levels change. Also, the return on a large incremental investment would be taxed at a rate somewhere between the $48 \%$ marginal rate and the actual average tax rate of the industry. 
3. The market penetration of vapor recompression is highly dependent on the relative price of electricity. If future electricity prices are expected to be relatively high, vapor recompression should not be funded because of low potential market penetration.

4. The market penetration of hydropyrolys is and the Rapson closed-cycle process is very favorable under all fuel price scenarios used. Thus, DOE should consider funding for these technologies if clear institutional or technological hurdles preventing further commercialization at this time can be demonstrated, but first, DOE should find out whether such hurdles do exist and should work to remove them.

5. Since the potential market penetration of new technologies can depend strongly on the availability and cost of other new technologies, it should be evaluated in an industrial environment indicative of the future mix of technologies and not of the present mix only.

6. A goal of decreased total energy consumption (including feedstocks) is not necessarily compatible with one of decreasing purchased energy use, though this also depends on the technology mix. DOE should decide which goal is more important and then use that goal to evaluate the conservation potential of technologies and institutional changes (e.g., lower paper quality). If the feedstocks are a renewable resource, as in the paper industry, probably minimizing purchased fuels should be aimed for within specific cost constraints.

7. Our analys is hints at the general conclusion that, in order to maximize energy saved per dollar of investment, any policy that makes investment in some conservation technologies more attractive should probably be applied equally to all conservation technologies. For example, we found that, when tax incentives were biased towards cogeneration, energy use actually increased compared to the case involving no change in tax incentives. This was because cogeneration incentives caused a drop in the cost of steam and electricity to the industry, encouraging their waste. 
